\title{
Catching investigation of yellowfin tuna (Thunnus Albacares) based on the distribution of chlorophyll-a in the North Waters of Aceh: A November and December analysis
}

\author{
Muhammad Irham ${ }^{1,2,3^{*}}$, Maulana Wali Akbar ${ }^{4}$, Mukhlis Mukhli5,2, Afdhal Fuadi ${ }^{6}$, Muhammad Authar ${ }^{7}$ and Ichsan \\ Setiawan ${ }^{1,3}$ \\ ${ }^{1}$ Department of Marine Sciences, Faculty of Marine and Fisheries, Universitas Syiah Kuala, Banda Aceh, Indonesia, 23111. \\ ${ }^{2}$ Geographical Information Systems Laboratory, Faculty of Marine and Fisheries, Universitas Syiah Kuala, Banda Aceh, Indonesia, \\ 23111. \\ ${ }^{3}$ Center for Environmental and Natural Resources Research (PPLH-SDA), Universitas Syiah Kuala, Banda Aceh, Indonesia, 23111. \\ ${ }^{4}$ Department of Fisheries Resource Utilization, Faculty of Marine and Fisheries, Universitas Syiah Kuala, Banda Aceh, Indonesia \\ 23111. \\ ${ }^{5}$ Marine and Fishery Resources Monitoring Base (PSDKP) Lampulo, Aceh, Indonesia 23127. \\ ${ }^{6}$ Aquatic Resources Study Program, Faculty of Fisheries and Marine Affairs, Teuku Umar University, Aceh Barat, Indonesia 23615. \\ ${ }^{7}$ Department of Agribusiness, Faculty of Agriculture, Universitas Malikussaleh, Lhokseumawe, Indonesia.
}

\begin{abstract}
The purpose of this study was to analyze the distribution of chlorophyll-a on the catch of yellowfin tuna in the northern waters of Aceh. This research was conducted in the north of Aceh waters starting from November to December 2020. fish catch data was collected by direct survey in the field by following the activities of fishermen and recording the number of catches. Data on chlorophyll-a was obtained from Aqua Modis satellite imagery. The catch data analysis used the CPUE model, while the chlorophyll-a analysis was carried out using the SeaDas 7.5 and ArcGIS. The results showed that the catch of yellowfin tuna was higher in November than in December as well as the distribution of chlorophyll-a content. The coefficient of determination (Adjusted R Square) is 0.09 , which means that the relationship between chlorophyll-a and yellowfin tuna catches is only $9 \%$, while $91 \%$ is influenced by other factors. These results inform that the content of chlorophyll-a does not show a significant relationship to the catch of yellowfin tuna.
\end{abstract}

\section{Introduction}

Aceh is one of the largest producers of tuna commodities, especially Yellowfin Tuna (Thunnus Albacares) [1,2], because it is surrounded by the Indian Ocean and Andaman Sea [3], and has a high selling value [4-6]. In 2012 yellowfin tuna production was 2,719 tons, in 2013 it was 3,656 tons and in 2016 production increased to 7,302 tons [7].

The distribution and abundance of yellowfin tuna is strongly influenced by several oceanographic parameters [8,9], one of which is chlorophyll-a $[10,11]$. Chlorophyll-a is one of the oceanographic biological parameters that plays an important role in primary productivity in the sea [12]. The distribution of chlorophyll-a contained in phytoplankton can be used as a measure of fertility in a water $[13,14]$. As a green pigment found in plants, chlorophyll-a use sunlight to carry out photosynthesis [15].

Phytoplankton needs chlorophyll-a, which is available in the photic layer, for the photosynthesis process [16]. Phytoplankton plays an important role as a source of nutrition for yellowfin tuna [17]. Although phytoplankton is not a natural food for yellowfin tuna, but it acts as a basic food chain [18]. Therefore, information about the distribution area of chlorophyll-a plays an important factor to determine the distribution of tuna fishing locations, especially yellowfin tuna [19].

Siregar et al., [20] found that yellowfin tuna were distributed in the southern area of Sumatra based on chlorophyll analysis. Bahri and Sari [21] also conducted research on the catchment area of yellowfin tuna through a morphometric approach from January to August 2017. The research shows that the northern and southern parts of Aceh waters have relatively higher catches compared to the western part of Aceh. However, the determination of fishing areas using the chlorophylla distribution approach in the northern waters of Aceh has not yet been carried out. Therefore, a study to determine the range of chlorophyll-a in the northern waters of Aceh which is used as a reference for information on yellowfin tuna fishing areas needs to be carried out. The purpose of this study was to analyze the distribution of chlorophyll-a as a yellowfin tuna fishing area in the northern coast of Aceh.

\footnotetext{
*Corresponding author: irham@unsyiah.ac.id
} 


\section{Method}

\subsection{Location, Time and Data Collection}

This research was carried out from November to December 2020 in the northern waters of the Aceh Province. Data collection in this study was carried out by observing primary data (data on fishing grounds by fishermen, time, and number of catches), and secondary data (satellite image data of chlorophyll-a). Data were collected by conducting interviews with 12 samples of ships and following a fishing trip.

The chlorophyll-a distribution data used in this study is Aqua-MODIS satellite image data which has been cleaned from cloud coverage and the data taken was in level 3. The downloaded chlorophyll-a image was a cloud-free image at the same time and location with yellowfin tuna fishing operations.

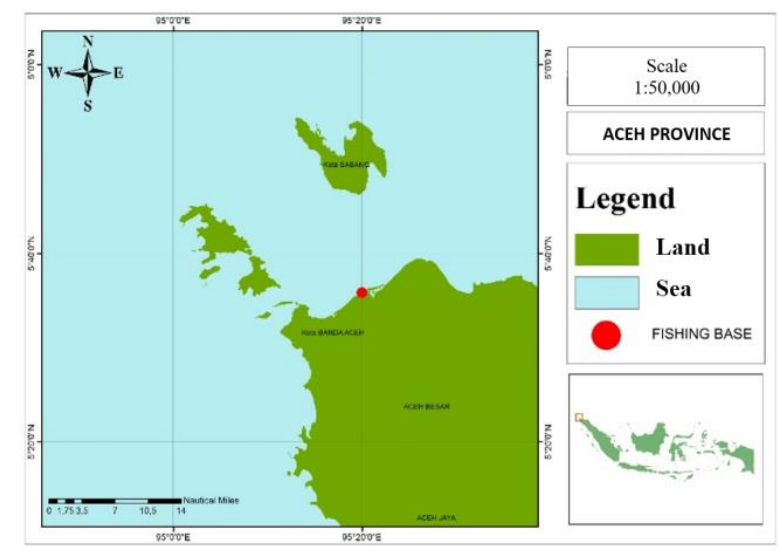

Figure 1. Research Area Map.

\subsection{Data Analysis}

Yellowfin tuna production data obtained during the study were used to calculate catch per unit effort (CPUE). The formula used to calculate CPUE is [22]:

where:

$$
C P U E=\frac{\text { catch }_{i}}{\text { effort }_{i}}
$$

CPUE $=$ Catch per fishing effort (kg/trip) in i-month catch $_{i}=$ Catch $(\mathrm{kg})$ in i-month

effort $_{i}=$ Attempt to catch (trip) in i-month

The CPUE value is then displayed in the form of a table based on. By looking at the catch, it can be categorized fluctuations in catches based on time and location/fishing area.

The chlorophyll-a data was then analyzed for temporal and spatial distribution. The following are the steps in processing chlorophyll-a which are downloaded from the Aqua Modis satellite image [23].

The relationship of chlorophyll-a to the catch of yellowfin tuna can be done by statistical analysis. The steps taken to determine each variable followed Bahri et al [21]. The relationship between chlorophyll-a and yellowfin tuna catch variables was carried out by simple linear regression analysis. The following are the provisions for the category of correlation values between variables $\mathrm{X}$ and $\mathrm{Y}$ (Table 1).
Table 1. Correlation value category used for statistical analysis.

\begin{tabular}{|c|c|}
\hline \multicolumn{2}{|c|}{ Multiple R Value } \\
\hline Very Low & $0.0-0.19$ \\
\hline Medium & $0.40-0.59$ \\
\hline Strong & $0.60-0.79$ \\
\hline Very Strong & $0.80-0.99$ \\
\hline
\end{tabular}

The yellowfin catch area based on the results of the catch analysis refers to [24] which states that:

1. If the CPUE value in the highest catch class is greater than the average CPUE, then the value for the catch is very good to be used as a very potential fishing area.

2. If the CPUE value is in the medium class, then the value for the catch is included in the potential fishing area.

3. If the CPUE value is in a very low class, then the value for the area can be classified into a fishing area with less potential for fishing grounds.

While criteria for the distribution of chlorophyll-a to yellowfin tuna fishing areas can be seen in the Table 2 below.

Table 2. Criteria for the the distribution of chlorophyll-a to yellowfin tuna fishing areas.

\begin{tabular}{|l|l|l|l|}
\hline No & chlorophyll-a & Category & DPI criteria \\
\hline 1 & $0.100<1.00 \mathrm{mg}^{3}$ & Optimum & Potential \\
\hline 2 & $1.00<2.00 \mathrm{mg}^{3}$ & Minimum & Not potnetial \\
\hline
\end{tabular}

\section{Result and Discussion}

\subsection{Result}

\subsubsection{Yellowfin Tuna Catch and CPUE Productivity}

The catch of yellowfin tuna in the northern waters of Aceh is fluctuating (Figure 2). Based on data from 12 vessels using handline fishing gear, the catch of yellowfin tuna in November amounted to $5,864 \mathrm{~kg}$. While the catch of yellowfin tuna in December was $3,342 \mathrm{~kg}$.

The decline in the production of catches in December is influenced by the number of fishing trips, weather conditions.

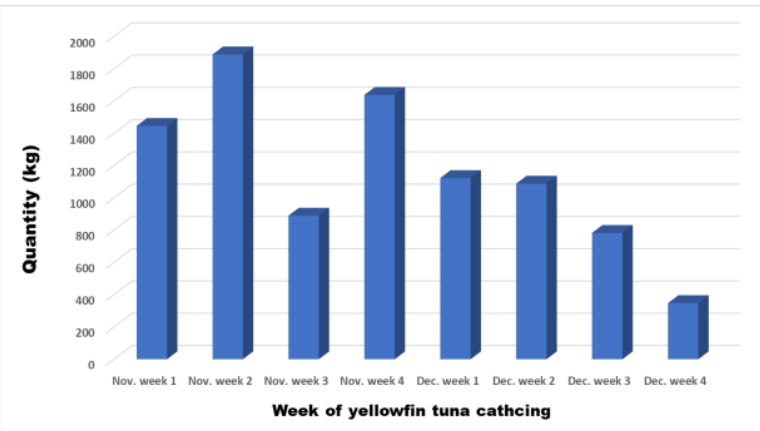

Figure 2. Yellowfin tuna catches in November and December 2020. 
The productivity of yellowfin tuna CPUE in November is $177 \mathrm{Kg} /$ trip and in December it is 138 $\mathrm{kg}$ /Trip. The total trips of fishing vessels that work in November are 33 trips while in December there are 25 trips.

\subsubsection{Distribution of Chlorophyll-a}

The distribution of chlorophyll-a content in the northern waters of Aceh can be seen in Figures 3 and 4. The distribution of chlorophyll-a content in the northern waters of Aceh in November 2020 ranged from 0.189 $\mathrm{mg} / \mathrm{m} 3$ to $1.082 \mathrm{mg} / \mathrm{m} 3$, with an average content of $0.635 \mathrm{mg} / \mathrm{m} 3$ in November 2020. The content of chlorophyll-a in November was relatively high with various variance values. In December 2020, the content of Chlorophyll-a ranged from $0.101 \mathrm{mg} / \mathrm{m} 3$ to 2.568 $\mathrm{mg} / \mathrm{m} 3$, with an average content of $1.258 \mathrm{mg} / \mathrm{m} 3$ in December 2020. The distribution of chlorophyll-a content in December was relatively low because it was dominated by the lowest variance value of $0.101 \mathrm{mg} / \mathrm{m} 3$. The data are represented in the Table 3 below.

Table 3. Chlorophyll-a distribution in November and December 2020

\begin{tabular}{|c|l|c|c|}
\hline \multirow{2}{*}{ No. } & \multirow{2}{*}{ Parameter } & \multicolumn{2}{c|}{ Distribution of chlorophyll-a } \\
\cline { 3 - 4 } & & November & December \\
\hline 1 & Chlorophyll-a & $0.189-1.082$ & $0.101-2.568$ \\
\hline 2 & High chlorophyll-a & 1.082 & 2.568 \\
\hline 3 & Low chlorophyll-a & 0.189 & 0.101 \\
\hline 4 & Avg. chlorophyll-a & 0.635 & 1,258 \\
\hline
\end{tabular}

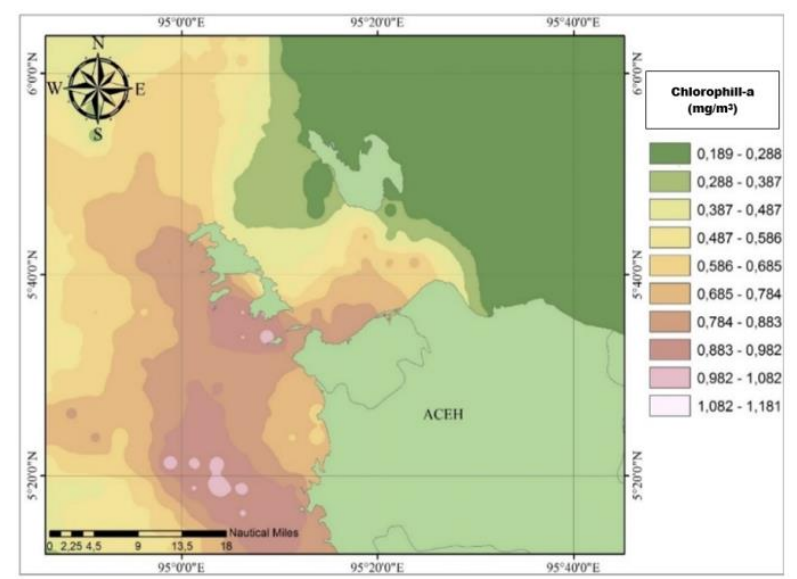

Figure 3. Map of distribution of chlorophyll-a content in the northern waters of Aceh Province in November 2020.

\subsubsection{The Relationship of Chlorophyll-A to Yellowfin Tuna Catches}

The relationship of chlorophyll-a with the catch of yellowfin tuna was obtained by performing a simple linear regression analysis. The relationship of chlorophyll-a with the catch of yellowfin tuna in November 2020 resulted in a coefficient of determination ( $\mathrm{R}$ Square) of 0.18 which means the relationship of chlorophyll-a with the catch of yellowfin tuna in November 2020 was $18 \%$ and the remaining $82 \%$. influenced by other factors. While the value of the correlation coefficient (Multiple R) between chlorophyll-a and the catch of yellowfin tuna is 0.42 , which means that chlorophyll-a has a moderate effect on the catch of yellowfin tuna.

The relationship of chlorophyll-a with the catch of yellowfin tuna in December 2020 resulted in a coefficient of determination (R Square) of 0.02, which means the relationship of chlorophyll-a with the catch of yellowfin tuna in December 2020 was $2 \%$ and the remaining $98 \%$. influenced by other factors. While the value of the correlation coefficient (Multiple R) between chlorophyll-a and the catch of yellowfin tuna is 0.14 which means that chlorophyll-a has a very low effect on the catch of yellowfin tuna.

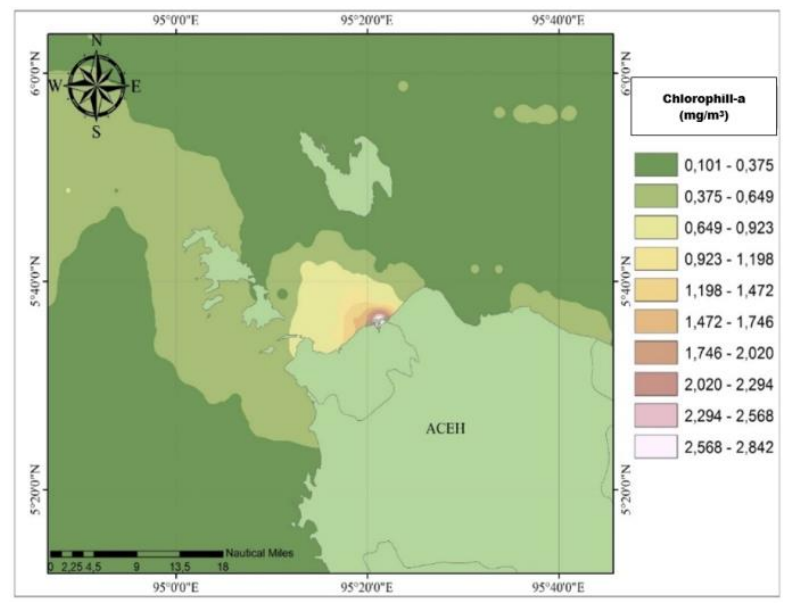

Figure 4. Map of distribution of chlorophyll-a content in the northern waters of Aceh Province in December 2020.

\subsubsection{The Potential Yellowfin Tuna Fishing Area}

Potential areas for catching yellowfin tuna in November and December 2020 are located in the northern waters of Aceh Island to the south-west waters of Aceh (Figure 5). Based on CPUE productivity, the total catch of the area is classified as a potential fishing area. Judging from the productivity of yellowfin tuna caught in these waters, which is relatively high. Meanwhile, the yellowfin tuna fishing areas that lack potential during November and December 2020 are in the northern waters of Sabang Island to the western waters of Sabang Island because the productivity (CPUE) of the fishing area tends to decrease in November and December 2020 .

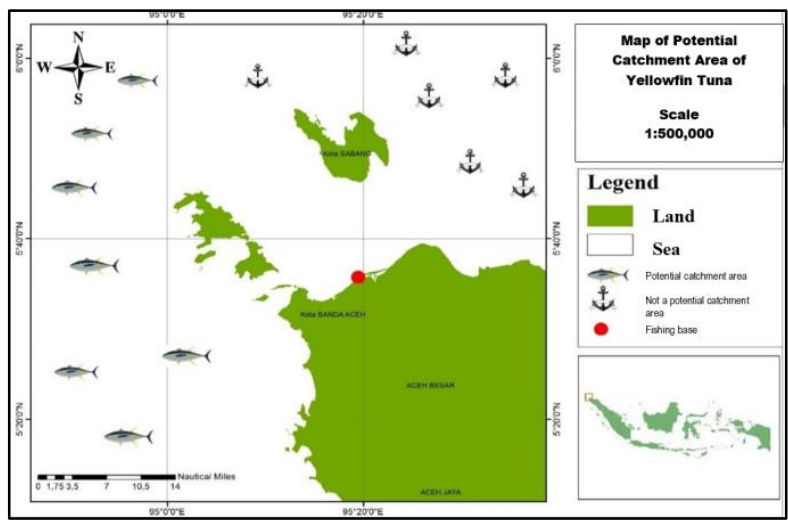

Figure 5. Potential fishing area of yellowfin tuna 


\subsection{Discussion}

The catch of yellowfin tuna in the northern waters of Aceh in November and December 2020 tends to fluctuate. This is due to changing fishing grounds, weather conditions and food availability. However, the main factor in the migratory behavior of large pelagic fish is food availability [25].

The decline in catch productivity in the northern waters of Sabang Island and the western waters of the Sabang Island was caused by weather factors, changing fishing areas, as well as the warning of the year-end Tsunami disaster in Aceh Province which resulted in fewer yellowfin tuna fishing trips by fishermen. However, determination of potential yellowfin tuna fishing areas is not representative enough to describe potential yellowfin tuna fishing areas if only based on productivity (CPUE). Therefore, another parameter is needed, such as the content of chlorophyll-a in these waters. Even though, the high CPUE productivity from yellow tuna fishing occurred in November and in December CPUE productivity was low.

Based on the results of simple linear regression analysis, the distribution of chlorophyll-a in November did not show a significant relationship to the catch of Yellowfin tuna. The results of the analysis show that the coefficient of determination (Adjusted R Square) produces a value of 0.09 , which means that the relationship between chlorophyll-a and yellowfin tuna catches in November 2020 is only $9 \%$ and the other $91 \%$ is influenced by other factors.

The results of linear regression analysis also showed that the distribution of chlorophyll-a in December also did not show a significant relationship to the catch of yellowfin tuna. yellowfin tuna in November 2020 was only $7 \%$ and the other $93 \%$ was influenced by other factors. The same finding was shown by Adnan [26] who stated that the relationship between chlorophyll-a concentration and the catch, the increase in the concentration of chlorophyll-a was linearly correlated with the increase in catch, and vice versa.

The results of the coordinate point data obtained from GPS fishermen, yellowfin tuna fishing in November 2020 was concentrated in the northern waters of the island of Aceh to the south-west waters of Aceh. In December 2020 yellowfin tuna fishing was concentrated in the northern waters to the western waters of Sabang Island (Figure 3 and 4).

yellowfin tuna catch in November 2020 in the northern waters of Aceh Island to the south-west waters of Aceh can be said to be a potential fishing area. The results of this analysis are supported by satellite image data of the distribution of chlorophyll-a in these areas compared to the data from satellite image in the northern waters of Sabang and the western waters of Sabang (Figure 3). Meanwhile, in December 2020, in the northern waters of the island of Sabang and the western area of the island of Sabang can be said to be a nonpotential fishing area, due to reduced catches and and the data of chlorophyll-a distribution from satellite image shows a low value of chlorophyll-a in the area of north of Sabang and west of Sabang waters (Figure 4).

\section{Conclusion}

The distribution of chlorophyll-a on the catch of yellowfin tuna had no significant effect in November 2020 because the coefficient of determination was only $18 \%$ and the other $82 \%$ was influenced by other factors. The same thing also happened in December 2020 with the coefficient of determination $2 \%$ and the other $98 \%$ influenced by other factors. Judging from the distribution of chlorophyll-a, the northern waters of Aceh Island to the south-west waters of Aceh are potential yellowfin tuna fishing areas, while the northern waters of Sabang Island and west of Sabang Island are non-potential yellowfin tuna fishing areas.

\section{References}

1. J. Burhanis, Z. Radmi, International Journal of Fisheries and Aquatic Studies, 5, 264 (2017)

2. Burhanis, Alaudin, Edwarsyah, Jaliadi, A. Rozi, Zulfadhli, R. Fadhillah, and Zulradmi, Utilization and optimization of the sustainability of yellowfin tuna (Thunnus albacares) in Simeulue waters, Aceh Indonesia, in IOP Conference Series: Earth and Environmental Science, 28 November 2020, Ambon, Indonesia (2021)

3. L. Campling, Journal of Agrarian Change, 12, 252 (2012)

4. M. Khaliqi, T.C. Pane, R.B.M.I. Fatoni, Indonesian tuna position in the international market, in IOP Conference Series: Earth and Environmental Science, 24-25 Oktober 2018, Sumatera Utara, Indonesia (2019)

5. B. Theophille, S.D. Hutchinson, A. Iton, Yellowfin Tuna in the Market for High Value Agricultural Products: Competitive Capability in Dominica, in CAES: 27th West Indies Agricultural Economics Conference, July 2007, Belize City, Belize (2009)

6. [KKP] Kementerian Kelautan dan Perikanan Indonesia, Statistik Perikanan Indonesia, (Jakarta, 2020)

7. [KKP] Kementerian Kelautan dan Perikanan Indonesia, Kelautan Dan Perikanan Dalam Angka 2017 (Jakarta, 2017)

8. M. Cornic, J.R. Rooker, Fisheries Research, 201, 1 (2018)

9. K. Nimit, N.K. Masuluri, A.M. Berger, R.P. Bright, S. Prakash, U. TVS, S.K.T.P. Rohit, T.A.S. Ghosh, S.P. Varghese, International Journal of Remote Sensing, 41, 5785 (2020)

10. B. Wiryawan, N. Loneragan, U. Mardhiah, S. Kleinertz, P. Wahyuningrum, J. Pingkan, Wildan, P. Timur, D. Duggan, I. Yulianto, Fishes, 5, 28 (2020)

11. R. Habibullah, Mubarak, M. Galib, Asian Journal of Aquatic Sciences, 3, 236 (2020)

12. J. Kovács, P. Tanos, G. Várbíró, A. Anda, S. Molnár, I.G. Hatvani, Ecological Indicators 78, 311 (2017) 
13. F. Aulia, M. Rusdi, A. Deli, A. Fuadi, M. Irham, I. Indra, The Marxan model for determining no-catch zones based on conservation targets in the northeastern region of Simeulue District, in IOP Conference Series: Earth and Environmental Science, 15-16 October 2020, Banda Aceh, Indonesia (2021)

14. M. A. Welliken, E.H. Melmambessy, S.L. Merly, R.D. Pangaribuan, B. Lantang, J. Hutabarat, A. Wirasatriya, Variability Chlorophyll-A and Sea Surface Temperature As the Fishing Ground Basis of Mackerel Fish in the Arafura Sea, in E3S Web of Conferences, 14-15 August 2018, Semarang, Indonesia (2018)

15. S. Siregar, A.B. Ternala, A.H. Zulham, Jurnal Aquacoastmarine, 4, 27 (2016)

16. X. Liu, E.A. Laws, Y. Xie, L. Wang, L. Lin, B. Huang, JGR:Biogeosciences, 124, 2400 (2019)

17. K. W. Lan, T. Shimada, M.A. Lee, N.J. Su, Y. Chang, Remote Sensing, 9, 444 (2017)

18. F. Lepori, Fundam. Appl. Limnol, 192, 305 (2019)

19. M. D. Setiawati, H.A. Rachman, A.R. As-syakur, A. Syahailatua, Identification of Commercial Tuna Hotspot in the Southern Waters of Java-Bali Through Satellite Remote Sensing Data, in 2021 IEEE International Geoscience and Remote Sensing Symposium IGARSS, 11-16 July 2021, Brussels, Belgium (2021)

20. Y. Siregar, E. Suri, V.P. Siregar, S.B. Agus, Jurnal Ilmu Dan Teknologi Kelautan Tropis, 10, 501 (2018)

21. S. Bahri, W.E. Sari, ALBACORE, 2, 307 (2018)

22. J. M. Petrere, J.P. Giacomini, J.P. De Marco, Braz. J. Biol, 70, 483 (2010)

23. M. Muklis, J.L. Gaol, D. Simbolon, J. Ilmu Teknologi Kelautan Tropis, 1, 24 (2009)

24. Y. J. Chang, C.L. Sun, Y. Chen, S.Z. Yeh, G. Dinardo, International Journal of Remote Sensing, 33, 7523 (2012)

25. S. Minarro, G.N. Ferero, H. Reuter, I.E. van Putten, Marine Policy, 69, 73 (2016)

26. A. Adnan, J PSP FPIK Unpatti, 1, 1 (2010) 